ACTA MYCOLOGICA

Vol. 42 (2): 211-217

2007
Dedicated to Professor Alina Skirgietto

on the occasion of her ninety-fifth birthday

\title{
Armillaria species in coniferous stands
}

\author{
ANNA ŻÓŁCIAK \\ Forest Research Institute, Sękocin Stary, Braci Leśnej 3, PL-05-090 Raszyn, A.Zolciak@ibles.waw.pl
}

Żółcia k A.: Armillaria species in coniferous stands. Acta Mycol. 42 (2):211-217, 2007.

Identification of the Armillaria species in selected coniferous stands (Scots pine stands, Norway spruce stands and fir stands) was the aim of the work carried out on the basis of mating tests and consideration of macroscopic traits of fruit bodies. One species of Armillaria [A. ostoyae (Romagnesi) Herink] was found in Scots pine stands, three species [A. ostoyae, $A$. cepistipes Velenovský and $A$. borealis Marxmüller et Korhonen] were found in Norway spruce stands and two species [A. ostoyae and $A$. cepistipes] were found in fir stands.

Key words: coniferous stands, Armillaria ostoyae, $A$. cepistipes, $A$. borealis

\section{INTRODUCTION}

Armillaria root infection is the most important disease affecting mainly young Scots pines (Pinus sylvestris L.) planted often in/after mixed stands in the north-east part of Poland and Norway spruce (Picea abies Karst.) stands in the south part of the country (Mańka 1953, 1998; Twarowski, Twarowska 1959; Twa row ska 1965; Rykowski 1985; Capecki 1994, 1997; Sierota 2001; Lech 2003; Mańka et al. 2003). It is caused by Armillaria species. From seven European Armillaria species, five were identified in Poland: A. borealis Marxmüller et Korhonen, A. cepistipes Velenovský, A. ostoyae (Romagn.) Herink, A. mellea (Vahl: Fr.) Kummer and $A$. gallica Marxmüller et Romagnesi (Żółciak 1999).

The objectives of the present study were to identify Armillaria species in selected coniferous stands: Scots pine stands, Norway spruce stands and fir stands in Poland and to determine the occurrence of Armillaria species considering forest habitat (according to Polish forest site typology) and stand age classes.

\section{MATERIALS AND METHODS}

Material (samples) consisted of fruit bodies of Armillaria, fragments of wood colonized by mycelium of Armillaria and rhizomorphs. Samples were taken from experimental one-time-sampled plots of $500 \mathrm{~m}^{2}$ each $(20 \mathrm{x} 25 \mathrm{~m})$ established in production stands: Scots pine stands, Norway spruce stands and fir stands. The stands were 
chosen on the basis of data obtained from questionnaires of the annual forest state assessments informing about the area of stands infested by root rot of Armillaria, inventory documents and the author's own observations.

One hundred and five plots were established in the Scots pine stands, situated within the territory of 52 Forest Districts (Fig. 1A). On each plot 1 to 10 samples were taken in 1985, 1989-94 and 1996-1998. Fifty plots were established in the Norway spruce stands, situated within the territory of 17 Forest Districts, 1 - in Gorce National Park and 1 - in Krynica Experimental Forest. On each plot 1 to 15 samples were taken in 1981, 1989, 1991, 1994, 1996-98 and 2001-03. Fifteen plots were establish in the fir stands, situated within the territory of 5 Forest District, 1 - in Gorce National Park and 1 - in Rotocze National Park. On each plot 1-12 samples were taken in 1991, 1994, 1996 and 1998. Characterization of the stands and samples is presented in table 1 .

The identification of Armillaria isolates was performed by using mating tests (Korhonen 1978). Fruit bodies of Armillaria were identified on the basis of the macro- and microscopic features (Romagnesi, Marxmüller 1983).

Table 1

Characterization of stands, from which samples of Armillaria were taken

\begin{tabular}{|c|c|c|c|c|c|c|c|}
\hline \multirow[t]{2}{*}{ Stands } & \multirow{2}{*}{$\begin{array}{l}\text { Age } \\
\text { of } \\
\text { stands }\end{array}$} & \multirow{2}{*}{$\begin{array}{l}\text { Type of } \\
\text { forest } \\
\text { habitat }^{*}\end{array}$} & \multirow{2}{*}{$\begin{array}{l}\text { Proportion } \\
\text { of main } \\
\text { species } \\
(\%)\end{array}$} & \multicolumn{4}{|c|}{ Number of the } \\
\hline & & & & $\begin{array}{l}\text { experi- } \\
\text { mental } \\
\text { plots }\end{array}$ & samples & 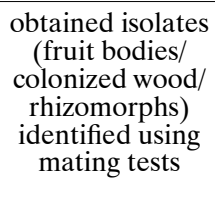 & $\begin{array}{c}\text { samples } \\
\text { (fruit bodies) } \\
\text { identified of } \\
\text { the macro- } \\
\text { and micro- } \\
\text { scopic } \\
\text { features }\end{array}$ \\
\hline $\begin{array}{l}\text { Scots } \\
\text { pine }\end{array}$ & $1-160$ & $\begin{array}{l}\text { FCF, } \\
\text { FMCF, } \\
\text { FMBF, } \\
\text { MMCF, } \\
\text { MMBF }\end{array}$ & $\begin{array}{l}100 \text { (Scots } \\
\text { pine) }\end{array}$ & 105 & 356 & $\begin{array}{c}176 \\
(71 / 105 /-)\end{array}$ & 180 \\
\hline $\begin{array}{l}\text { Norway } \\
\text { spruce }\end{array}$ & $1-120$ & $\begin{array}{l}\text { FMCF, } \\
\text { FBF, } \\
\text { FMBF, } \\
\text { MUF, } \\
\text { MMF, } \\
\text { MF }\end{array}$ & $\begin{array}{l}60-100 \\
\text { Norway } \\
\text { spruce }\end{array}$ & 50 & 228 & $\begin{array}{c}114 \\
(86 / 27 / 1)\end{array}$ & 114 \\
\hline fir & $41-140$ & $\begin{array}{l}\text { FBF, } \\
\text { UF, } \\
\text { MMF, } \\
\text { MF }\end{array}$ & $\begin{array}{l}50-100 \\
\text { (fir) }\end{array}$ & 15 & 53 & $\begin{array}{c}25 \\
(23 / 2 /-)\end{array}$ & 28 \\
\hline \multicolumn{4}{|c|}{ Total } & 170 & 637 & $\begin{array}{c}315 \\
(180 / 134 / 1)\end{array}$ & 322 \\
\hline
\end{tabular}

Explanations: fresh coniferous forest $(\mathrm{FCF})$, fresh mixed coniferous forest (FMCF), moist mixed coniferous forest (MMCF), fresh broadleaved forest (FBF), fresh mixed broadleaved forest (FMBF), upland forest (UF), mixed upland forest (MUF), moist mixed broadleaved forest (MMBF), mountain forest (MF), mixed mountain forest (MMF). 


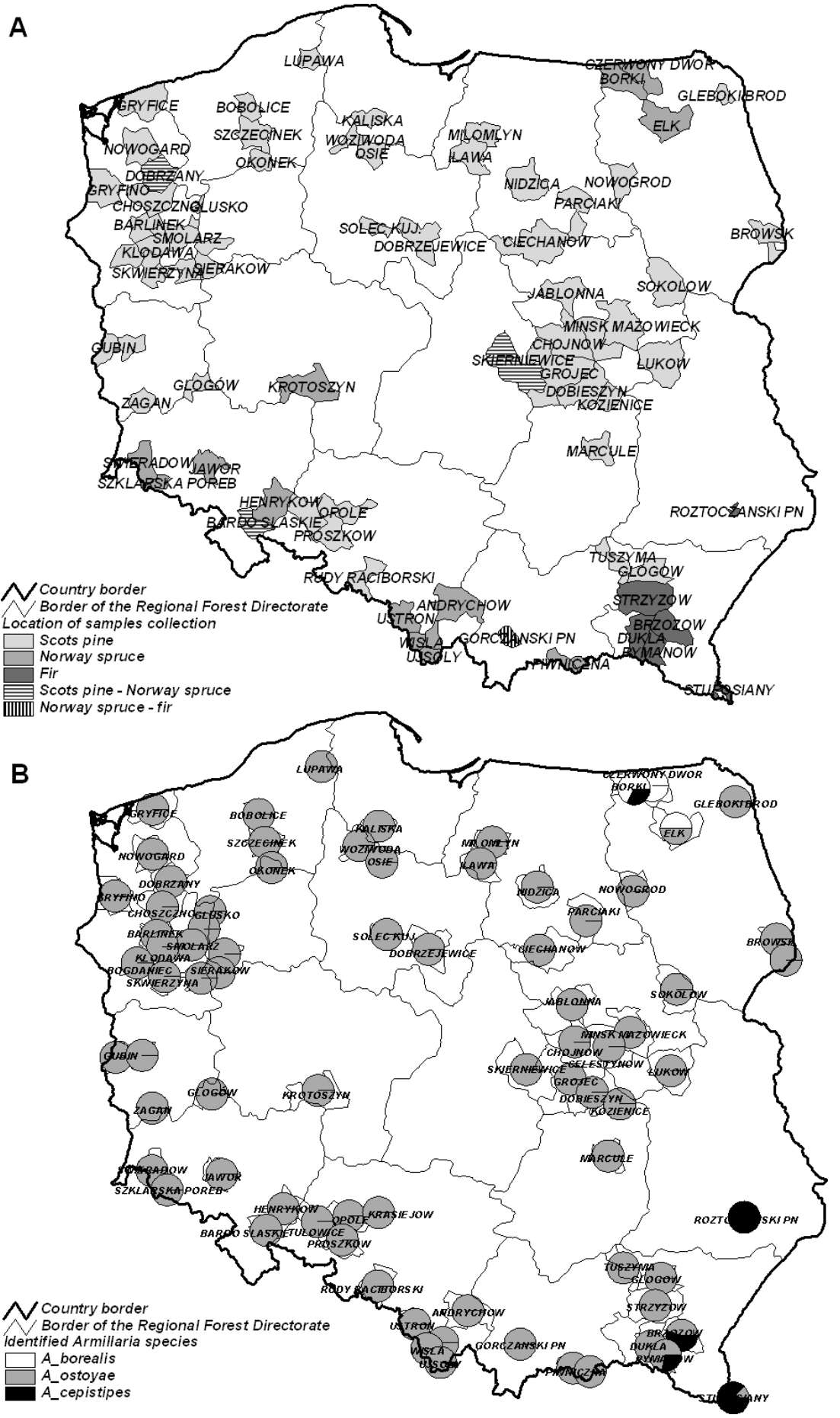

Fig. 1. A) Distribution of experimental plots. B) Distribution of Armillaria species in Scots pine stands, Norway spruce stands and fir stands. 


\section{RESULTS}

A total of 637 samples were collected in the investigated coniferous stands (356 samples - in Scots pine stands, 228 samples - in Norway spruce stands and 53 samples - in fir stands). The proportions of Armillaria samples found in the coniferous stands were calculated (Tabs 2 and 3).

Table 2

Percentage of samples of Armillaria from coniferous stands: Scots pine, Norway spruce and fir considering different types of forest habitat

\begin{tabular}{|c|c|c|c|c|c|c|c|c|c|c|}
\hline \multirow{2}{*}{ Stands } & \multicolumn{10}{|c|}{ Type of forest habitat } \\
\cline { 2 - 12 } & $\begin{array}{c}\text { FCF } \\
(\%)\end{array}$ & $\begin{array}{c}\text { FMCF } \\
(\%)\end{array}$ & $\begin{array}{c}\text { MMCF } \\
(\%)\end{array}$ & $\begin{array}{c}\text { FBF } \\
(\%)\end{array}$ & $\begin{array}{c}\text { FMBF } \\
(\%)\end{array}$ & $\begin{array}{c}\text { MMBF } \\
(\%)\end{array}$ & $\begin{array}{c}\text { UF } \\
(\%)\end{array}$ & $\begin{array}{c}\text { MUF } \\
(\%)\end{array}$ & $\begin{array}{c}\text { MMF } \\
(\%)\end{array}$ & $\begin{array}{c}\text { MF } \\
(\%)\end{array}$ \\
\hline Scots pine & 9,3 & 78,4 & 5,6 & 0,8 & 4,8 & 1,1 & - & - & - & - \\
\hline Norway spruce & 0,9 & - & - & 2,6 & 12,7 & - & - & 13,6 & 36,4 & 33,8 \\
\hline Fir & - & - & - & 3,8 & - & - & 45,3 & - & 3,8 & 47,1 \\
\hline
\end{tabular}

Table 3

Percentage of samples of Armillaria from coniferous stands: Scots pine stands, Norway spruce stands and fir stands considering different stand age classes

\begin{tabular}{|c|c|c|c|c|c|c|c|c|}
\hline \multirow{2}{*}{ Stands } & \multicolumn{8}{|c|}{ Stand age classes } \\
\cline { 2 - 9 } & $\begin{array}{c}1-20 \\
(\%)\end{array}$ & $\begin{array}{c}21-40 \\
(\%)\end{array}$ & $\begin{array}{c}41-60 \\
(\%)\end{array}$ & $\begin{array}{c}61-80 \\
(\%)\end{array}$ & $\begin{array}{c}81-100 \\
(\%)\end{array}$ & $\begin{array}{c}101-120 \\
(\%)\end{array}$ & $\begin{array}{c}121-140 \\
(\%)\end{array}$ & $\begin{array}{c}141-160 \\
(\%)\end{array}$ \\
\hline Scots pine & 84,8 & 0,6 & 1,7 & 7,0 & 2,2 & 2,8 & 0,6 & 0,3 \\
\hline Norway spruce & 2,2 & 1,3 & 38,6 & 45,6 & 11,4 & 0,9 & - & - \\
\hline Fir & - & - & 5,7 & 7,5 & 26,4 & 37,7 & 22,6 & - \\
\hline
\end{tabular}

Only one species of Armillaria - A. ostoyae was found in the Scots pine stands, three species: $A$. ostoyae, $A$. cepistipes and $A$. borealis were found in the Norway spruce stands and two species: $A$. ostoyae and $A$. cepistipes were found in the fir stands (Fig. 1B). In the Norway spruce stands, among the identified isolates and fruit bodies belonging to genus Armillaria, the species $A$. ostoyae attained the highest proportion $-85,5 \%$. The remaining ones were less frequent: $A$. borealis $-11,4 \%$ and $A$. cepistipes $-3,1 \%$. In the fir stands share of $A$. ostoyae was $51,2 \%$ and share of A. cepistipes was $48,8 \%$. In the Scots pine stands the species $A$. ostoyae was found in six forest site types, mainly in fresh mixed coniferous forest (Tab. 4). In the Norway spruce stands all the three identified species were found in fresh mixed broadleaved forest site type. The species $A$. ostoyae was recorded in six investigated site types. $A$. borealis was found in fresh broadleaved forest site type and fresh mixed broadleaved forest site type. A. cepistipes was found in fresh mixed broadleaved forest site type, mixed mountain forest site type, and mountain forest site type. In the fir stands A. ostoyae was noticed on three forest site types: upland forest, mountain forest and mixed mountain forest, A. cepistipes - in fresh broadleaved forest, upland forest, and mountain forest. 
Table 4

Percentage of particular Armillaria species in samples from coniferous stands from different types of forest habitat

\begin{tabular}{|c|c|c|c|}
\hline \multirow{2}{*}{ Type of forest habitat } & \multicolumn{3}{|c|}{ Species of Armillaria } \\
\hline & A. borealis (\%) & A. cepistipes (\%) & A. ostoyae $(\%)$ \\
\hline \multicolumn{4}{|c|}{ Scots pine stands } \\
\hline FCF & - & - & 9,3 \\
\hline FMCF & - & - & 78,4 \\
\hline MMCF & - & - & 5,6 \\
\hline FBF & - & - & 0,8 \\
\hline FMBF & - & - & 4,8 \\
\hline MMBF & - & - & 1,1 \\
\hline \multicolumn{4}{|c|}{ Norway spruce stands } \\
\hline FMCF & - & 28,6 & 0,9 \\
\hline FBF & 3,8 & - & 2,6 \\
\hline FMBF & 96,2 & - & 12,7 \\
\hline MUF & - & - & 13,6 \\
\hline MMF & - & 57,1 & 36,4 \\
\hline MF & - & 14,3 & 33,8 \\
\hline \multicolumn{4}{|c|}{ fir stands } \\
\hline FBF & - & 9,5 & - \\
\hline UF & - & 38,1 & 50,0 \\
\hline MMF & - & - & 6,2 \\
\hline MF $^{\prime}$ & - & 52,4 & 43,8 \\
\hline
\end{tabular}

Table 5

Percentage of particular Armillaria species in samples from coniferous stands of different stand age classes

\begin{tabular}{|c|c|c|c|}
\hline \multirow[t]{2}{*}{ Stand age classes } & \multicolumn{3}{|c|}{ Species of Armillaria } \\
\hline & A. borealis (\%) & A. cepistipes (\%) & A. ostoyae (\%) \\
\hline \multicolumn{4}{|c|}{ Scots pine stands } \\
\hline $1-20$ & - & - & 84,8 \\
\hline $21-40$ & - & - & 0,6 \\
\hline $41-60$ & - & - & 1,7 \\
\hline $61-80$ & - & - & 7,0 \\
\hline $81-100$ & - & - & 2,2 \\
\hline $101-120$ & - & - & 2,8 \\
\hline $121-140$ & - & - & 0,6 \\
\hline $141-160$ & - & - & 0,3 \\
\hline \multicolumn{4}{|c|}{ Norway spruce stands } \\
\hline $1-20$ & - & - & 2,2 \\
\hline $21-40$ & - & - & 0,9 \\
\hline $41-60$ & 88,5 & 57,1 & 8,8 \\
\hline $61-80$ & 3,8 & 14,3 & 75,4 \\
\hline $81-100$ & 7,7 & 28,6 & 8,3 \\
\hline $101-120$ & - & - & 4,4 \\
\hline \multicolumn{4}{|c|}{ fir stands } \\
\hline $41-60$ & - & - & 9,4 \\
\hline $61-80$ & - & 9,5 & 6,2 \\
\hline $81-100$ & - & 23,8 & 28,1 \\
\hline $101-120$ & - & 42,9 & 31,3 \\
\hline $121-140$ & - & 23,8 & 25,0 \\
\hline
\end{tabular}


A. ostoyae was found most frequently in the 1-20-year-old Scots pine stands $(84,8 \%)$, in the $61-80$-year-old Norway spruce stands $(75,4 \%)$ and in the $101-120$ year-old fir stands (31,3\%; Tab. 5). A. borealis and A. cepistipes were noticed mainly in the 41-60-year-old Norway spruce stands. $A$. cepistipes was collected particularly in the 101-120-year-old fir stands.

\section{CONCLUSIONS}

A. ostoyae seems to be the most frequent species of Armillaria in coniferous stands in Poland. It was found in the all investigated stands ( $100 \%$ in pine, $85,5 \%$ in Norway spruce and $51,2 \%$ in fir stands), in all types of forest habitat and in all stand age classes. It is in concordance with findings of many authors that $A$. ostoyae is responsible for most cases of Armillaria attacks in conifers (Guillaumin, Berthelay 1981; Rishbeth 1982; Roll-Hansen 1985; Guillaumin et al 1985; Rykowski 1990; Guilla umin et al 1993).

$A$. borealis was found only in the older (41-100-years-old) Norway spruce stands in fertile forest site types (FBF, FMBF). A. cepistipes was noticed in the older Norway spruce and fir stands and in many forest site types except for weak coniferous ones. Over $50 \%$ of samples of that species were collected in the mountain sites.

Acknowledgement. I gratefully acknowledge Dr Kari Korhonen from the Finnish Research Institute for the testers of Armillaria.

\section{REFERENCES}

Cape cki Z. 1994. Rejony zdrowotności lasów zachodniej części Karpat. (Forest health condition regions in western Carpathians). Prace Inst. Bad. Leśn. A, 781: 83-191.

Ca pe ck i Z. 1997. Rejonizacja zdrowotności lasów środkowej części Karpat. (Regions of differing health in the central part of the Carpathians). Prace Inst. Bad. Leśn. A, 840: 83-191.

Guilla u min J. J., Berthelay S. 1981. Détermination spécifique des armillaires par la méthode des groupes de compatibilité sexuelle. Spécialisation écologique des espèces françaises. Agronomie 1: 897-908.

Guilla umin J. J., Lung B., Romagnesi H., Marxmüller H., Lamoure D., Durrieu G., Berthelay S., Mohamed C. 1985. Systématique des Armillaires du groupe Mellea. Conséquences phytopathologiques. Eur. J. For. Path. 15: 268-277.

Guillau min J. J., Mohamed C., Anselmi N., Courtecuisse R., Gregory O., Holdenrieder O., Intini M., Lung B., Marxmüller H., Morrison D., Rishbeth J., Termorshuizen A. J., Tir ró A., Va n D a m B. 1993. Geographical distribution and ecology of the Armillaria species in western Europe. Eur. J. For. Path. 23: 321-341.

Kor h on en K. 1978. Interfertility and clonal size in the Armillaria mellea complex. Karstenia 18: 31-42.

Lech P. 2003. Zagrożenie drzewostanów świerkowych w Polsce przez patogeny korzeni w świetle wyników monitoringu fitopatologicznego lasów gospodarczych. (In:) A. G r zyw a cz (ed.). Drzewostany świerkowe - stan, problemy, perspektywy rozwojowe. Materiały Sesji Naukowej PTL, UstronJaszowiec: 92-107.

M a ń k a K. 1953. Badania terenowe i laboratoryjne nad opieńką miodową-Armillaria mellea (Vahl) Quél. Prace Inst. Bad. Leśn. 94: 1-96.

Mańk a K. 1998. Fitopatologia leśna. PWRiL. Warszawa. 368 pp.

Mańka M., Przybył K., Małecka M. 2003. Choroby świerka na tle zmian środowiska. (In:) materiałach Sesji Naukowej PTL, Drzewostany świerkowe: stan, problemy, perspektywy rozwojowe. Ustroń-Jaszowiec: 63-76.

Rish beth J. 1982. Species of Armillaria in southern England. Pl. Path. 31: 9-17.

Roll-Ha ns en F. 1985. The Armillaria species in Europe. Eur. J. For. Path. 15: 22-31. 
Romagnesi H., Marx mülle r H. 1983. Etude complémentaire sur les armillaires annelées. Bull. Soc. Mycolog. de France 99: 301- 324.

Rykowski K. 1985. Niektóre troficzne uwarunkowania patogeniczności Armillaria mellea (Vahl) Quèl. w uprawach sosnowych. Prace Inst. Bad. Leśn. 640: 1-140.

Rykowski K. 1990. Opieńkowa zgnilizna korzeni. PWRiL. Warszawa. 16 pp.

Si e r o ta Z. 2001. Choroby lasu. Centrum Informacyjne Lasów Państwowych. 156 pp.

Tw a rows k a I. 1965. Opieńka miodowa. PWRiL Warszawa. 54 pp.

Tw a r ow ski Z., Tw a row sk a I. 1959. Studies and observations on Armillaria mellea (Vahl) Quél. as the cause of mass dying-off of forest stands. Prace Inst. Bad. Leśn. 192: 1-61.

Żółcia k A. 1999. Identyfikacja gatunków grzybów z rodzaju Armillaria (Fr.: Fr.) Staude w Polsce. Prace Inst. Bad. Leśn. 888: 3-19.

\section{Opieńki w drzewostanach iglastych}

Streszczenie

Materiał badawczy (owocniki, fragmenty drewna przerośniętego grzybnią, ryzomorfy) pobierano w różnych latach, na jednorazowych powierzchniach w wybranych drzewostanach iglastych: sosnowych, świerkowych i jodłowych. Izolaty identyfikowano za pomocą testów intersterylności. Owocniki identyfikowano na podstawie cech makroskopowych i mikroskopowych. Wśród badanych próbek stwierdzono trzy gatunki opieniek. Stwierdzono w drzewostanach: sosnowych $-A$. ostoyae, świerkowych $-A$. ostoyae, $A$. borealis i $A$. cepistipes, jodłowych -A. ostoyae i $A$. cepistipes. A. ostoyae wydaje się być jednym z najczęściej występujących gatunków opieniek w drzewostanach iglastych w Polsce. Stwierdzono ten gatunek we wszystkich badanych drzewostanach iglastych. Jego udział stanowił $100 \%$ prób zebranych w drzewostanach sosnowych, 85,5\% - w drzewostanach świerkowych oraz 51,5\% - w drzewostanach jodłowych. A. ostoyae stwierdzono na wszystkich typach siedliskowych lasu i w drzewostanach we wszystkich klasach wieku. $A$. borealis stwierdzono tylko w drzewostanach świerkowych, w wieku 41-100 lat, na bogatych siedliskach. A cepistipes stwierdzono w drzewostanach świerkowych i jodłowych, w starszym wieku, na większości badanych siedlisk. 